\title{
Bill of Sale Lending: Reforming a "Toxic" Form of Credit
}

\section{Key words: Lender, Borrower, Bills of Sale, Logbook Loans, Reforms, Law Commission.}

Bills of sale allow individuals in the UK to use 'goods' ${ }^{1}$ that they own as security for a loan, while retaining possession of those goods, so-called security bills of sale. They represent an archaic regime created by Victorian legislation to allow Victorian individuals to borrow against then every-day items such as pots and pans, antiques, paintings and indeed any articles capable of complete transfer by delivery. ${ }^{2}$ On the face of things this appears to a simple arrangement but underlying this there is a highly complex regime that is little understood by both debtors and lenders. ${ }^{3}$ Proposals for large scale reform by the Law Commission and the Government decision to introduce a new Goods Mortgages Act by 2019 fit for purpose in the $21^{\text {st }}$ Century are, therefore, long overdue to reform this area of law. ${ }^{4}$

Today bills of sale are often used in relation to motor vehicles, as such contracts are often referred to as "logbook loans". ${ }^{5}$ The manifestly unfair treatment of consumers in these contracts has received considerable recent media coverage. The unfair nature of such contracts extends both to the initial borrowers and also to third party purchasers buying second-hand motor vehicles that are still subject to the original loan. It is important to understand that third party purchasers of motor vehicles subject to such a logbook loan fall outside of the protection provided by Part III of the Hire Purchase Act 1964. Section 27 of Part III provides that if the borrower disposes of a motor vehicle subject to a hire purchase agreement or a conditional sale agreement before the property in the motor vehicle has become vested in the borrower, then the disposition to a private purchaser of the vehicle in good faith and without notice of the hire purchase or conditional sale agreement takes effect as if the lender's title to the vehicle has been vested in the borrower immediately prior to the disposition. Non-private purchasers, such as car dealers, do not have any such protection.

Such was the level of concern generated by Citizens Advice analysis of the market, its Chief Executive has labelled some lenders as 'predatory' and the form of credit as 'toxic'. Borrowers using the loans are often in acute financial strife and accept high cost arrangements and may not understand the out-dated language, which governs bills of sale. Furthermore, the ability for a lender to seize a vehicle without a court order when, for

\footnotetext{
${ }^{1}$ Technically the word 'goods' should refer to 'chattels', but this will be referred to as 'goods' for the purpose of this article's main text.

${ }^{2}$ See James Weir, The Law of Bills of Sale (Jorden \& Sons, 1896) p.23 and the example of a bill of sale extending to, 'all and every the household goods, furniture, plate, linen, china, books, stock-in-trade, brewing utensils and all the other effects' of the grantor.

${ }^{3}$ Bills of Sale Act 1878 and the Bills of Sale (1878) Amendment Act 1882.

${ }^{4}$ The call for reform in this area has been longstanding. See Crowther, Report of the Committee on Consumer Credit, Vol 1, (1971), Cmnd4596, p.179; Diamond, A Review of Security Interests in Property (1989) p 92, para 18.1.8; Law Commission, Company Security Interests (2005) No 296. NB: Secured Transaction Law Reform Project contribution to this discussion available https://securedtransactionslawreformproject.org/discussion-papers/ (Accessed 19 July 2017).
}

${ }^{5}$ The use of the phrase 'logbook loans' is not a legal one. It is referring to the surrendering of the vehicle registration document by the borrower to the lender. This has no legal effect and is simply symbolic. 
example, the borrower falls behind on payments, means debt collection practices are poor and even threatening.

These concerns are heightened by the fact that the use of such bills has exploded in number from approximately 3,000 in 2001 to over 30,000 in 2016, which mirrors payday loans before regulation reformed that area. Typical Annual Percentage Rates are $400 \%$ or more, making it an expensive form of credit. ${ }^{6}$ The position is exacerbated by the fact that $37 \%$ of people with logbook loans also had one or more payday loans. ${ }^{7}$ Addressing the widespread concerns relating to irresponsible lending and vehicles being readily seized has become part of a vital response to the wider issues surrounding consumer indebtedness.

Arguably the Law Commission's recommendations for reform would improve the terminology for borrowers, allow them greater redress to the courts and also give a right to end the agreement early and hand the vehicle back. Private purchasers of a motor vehicle in good faith and without knowledge of the logbook loan agreement entitle such a purchaser to take free of the lender's title to the vehicle.

While introducing new safeguards for consumers, the new regime would at the same time potentially expand the market by simplifying the complex arrangements for the registration of documents by a lender and mitigating the consequences to a lender if the right process is not followed.

The ability to use goods other than vehicles to raise money against is, while less publicised, also important. ${ }^{8}$ While the Bills of Sale Acts do not apply to companies, consumers, sole traders and partnerships use them. A modernised regime may better allow cash to be raised against valuable assets, such as stock, office equipment and book debts, and thus support small unincorporated businesses in raising money against such assets. Furthermore, a security bill of sale can only be raised against a loan of a fixed amount therefore depriving such businesses of the facility of revolving credit or an overdraft. By reforming the law on bills of sale there is an opportunity for business loans to be secured on goods. The recommendations to modernise the cumbersome High Court registration system and changes to the documentation are key to such an objective.

This article commences by exploring the operational background (Part A) to the current regime, before setting out the particular concerns for consumers (Part B) and businesses (Part C) and then critically considers the recommendations for change (Part D) noting issues in relation to the proposed registration process and concerns about the effectiveness of the proposals in securing an appropriate balance between making credit available and the consequences of over indebtedness for vulnerable consumers.

\footnotetext{
${ }^{6}$ The Money Advice Service, https://www.moneyadviceservice.org.uk/en/articles/logbook-loans (Accessed 14 August 2017).

${ }^{7}$ Law Commission, Bills of Sale: A Consultation (Law Com No 225, 2015) para 2.16.

${ }^{8}$ Goods such as bottles of wine and spirits, antiques and paintings, musical instruments, cars, caravans, motorhomes and yachts can all be used to secure credit. For smaller items in the consumer context, however, pawning is often used where an entirely different regime applies. In the non-consumer context, a steam engine, a hotel's fixtures and fittings and a herd of cows are all examples of goods used to secure a bill of sale.
} 


\section{A. The Operational Background}

A bill of sale was defined by Lord Esher M.R. in Mills $v$ Charlesworth in the following terms:

"A bill of sale, in its ordinary meaning, is the document which is given where the legal property in goods passes to the person who lends money on them, but the possession does not pass." ${ }^{\prime 9}$

A security bill of sale therefore allows a borrower to transfer the legal title to his personal goods to the lender and in exchange the lender will advance credit to the borrower in exchange for periodic repayments whilst retaining borrower possession of the goods. If, however, the borrower misses a payment the lender can automatically seize the goods without a court order as he has legal title because a security bill contains a clause to allow the lender to take possession. This is one of the central problems with bills of sale since at common law the lender (or logbook lender in the case of a motor vehicle) gains legal title and becomes the owner of the vehicle and as such has an immediate right of possession. Essentially the lender is a mortgagee and as stated by Harman J. in Four Maids Ltd $v$ Dudley Marshall Properties) Ltd a "mortgagee may go into possession before the ink is dry on the mortgage unless there is something in the contract, express or by implication, whereby he has contracted out of that right" ${ }^{\prime 10}$. The 1882 Act limits the right of the lender to seize the goods or motor vehicle to one of four reasons, however one of these reasons is the default of repayment by the borrower ${ }^{11}$ which of course is the principal reason for the lender seizing the goods.

One further aspect of the bill of sale is that since the debtor retains possession of the goods, he is able to dispose of the goods to a third-party purchaser who is unaware as to the bill of sale held by the lender. The result is that if the borrower defaults on his repayments then the lender, having good legal title to the goods, is able to seize the goods at will from the third-party buyer. This is the case even if the buyer has bought the good in good faith and with no notice of the logbook loan under the bill of sale. This would leave the third party with a number of unattractive choices, if the lender is willing to accept the first two options:

(i) Pay off the loan due to the lender;

(ii) Pay the lender for the goods again; or

(iii) Surrender the goods.

The first two of these choices are not in themselves without some difficulties. It must be remembered that the purchaser has no rights in the property whatsoever as the borrower has already surrendered any rights he may have had to the lender and therefore cannot pass any rights on to the third party. The effect of this is that the third party cannot insist on the lender allowing him to pay off the debt, indeed the lender may ask for more than the

\footnotetext{
${ }^{9}$ (1880) L.R. 25 Q.B.D. 421 at 425.

${ }^{10}$ [1957] Ch 317 at 320.

${ }^{11}$ Bill of Sale (1878) Amendment Act 1882 s.7
} 
outstanding debt owed by the borrower. While the third party could in principle sue the borrower, who sold them the goods without providing good title, ${ }^{12}$ this would most likely be a fruitless exercise given that the borrower is probably a "man of straw" who has been deemed by the Law Commission to be a "sub-prime borrower."13

While the origin of the bills of sale is in the common law, they become controlled in Victorian times by way of the Bills of Sale Acts.

The intention of the Bill of Sale Act 1878 (BSA 1878) was to control the granting of bills of sale, given the potential for hardship caused by the borrower retaining possession of the goods against which credit has been extended so enabling secret dispositions of them to another person. The Act however had a double function in that it not only gave a limited degree of protection to borrowers but also it was intended to prevent fraud not only on potential purchasers but also potential lenders both of whom could be misled into believing that the borrower still owned the goods. The Act therefore was an attempt at controlling a "false wealth" culture by requiring bills of sale to be registered so that potential purchasers and lenders could check whether the goods in question were the subject of a bill of sale. The Act therefore provided that any unregistered bill of sale was rendered void against lenders or trustees in bankruptcy enforcing their security, where the goods remained in possession of the borrower. The documentation required and process for registration is, however, complex and out-dated.

The Bill of Sale (1878) Amendment Act 1882 (BSA(1878)AA) only relates to security bills of sale and was an early response to the need for consumer protection and in that respect it provides some protection against a needy borrower being caught by complex and often incomprehensible documents with the result that they run the risk of being subject to harsh and onerous enforcement provisions. The protection embodied within the Act takes the form of a prescribed statutory bill of sale that sets out the nature and terms of the loan. Further, the Act restricts the terms that can be inserted into a security bill of sale. Of course, in Victorian times consumer protection was extremely limited ${ }^{14}$ and the law was only then beginning to move away from the classic theory of freedom of contract embodied in the notion of caveat emptor, to an era of social protectionism. In fact, the Act did little to protect the then "consumers" and this position remains the same today.

There are, as such, two main areas for criticism:

(i) There is extreme complexity for meeting the compliance requirement for the documentation and registration processes; and

(ii) The lender has significant protection, but only if they follow the process to the letter (see below), while the borrower has very limited protection and an innocent third-party buyer none.

\footnotetext{
${ }^{12}$ See the Sale of Goods Act 1979, s.12.

${ }^{13}$ Law Commission, Bills of Sale: A Consultation (Law Com No 225, 2015) paras 1.5; 2.4; 4.84 and 5.2.

${ }^{14}$ See Carlill v Carbolic Smoke Ball Company [1892] EWCA Civ 1
} 
It is in light of this that the Law Commission was asked to investigate the possibility of reform by HM Treasury in September 2014. The decision not to simply withdraw bills of sale is reflective of the need for flexible forms of credit lending, essential for businesses to operate and grow and also for consumers to effectively budget while enjoying improved living and social standards. ${ }^{15}$

Indeed, the origins of bills of sales are reflective of that importance. The ways in which the bills of sale protected a lender underlines the importance of the ways in which credit was advanced in Victorian England and, unlike pawnbroking bills of sale allowed a borrower to keep possession and make use the goods. The effect was that a borrower could retain the goods and maintain a semblance of wealth to outsiders. This was particularly important in Victorian England when the concepts of credit and debt were closely associated with a person's character, social status and adherence to the moral standards of that era. Debt was not seen as an economic circumstance but as a moral failure to be accorded punishment by incarceration in a debtor's prison. Often this approbation was directed at the working classes who were often regarded as defaulting on their debts deliberately and treated harshly, unlike the middle and upper classes that were often treated more leniently on the basis that they had an honest intention to pay their debts. Bills of sale therefore allowed a borrower to maintain an outward appearance "wealth" in the knowledge that if the borrower defaulted the debtor's prison may be avoided by the lender seizing the goods. It should be noted however that the lender is entitled to seize the goods even if most of the debt has been repaid and indeed such seizure does not eliminate the debt so that a borrower may be left with a large and increasingly outstanding amount to repay.

\section{Documentation and Registration Requirements for a Bill of Sale}

A bill of sale will be void (even against the lender) if it is not registered within seven clear days at the High Court ${ }^{16}$ and in the correct form. ${ }^{17}$

The Bill of Sale (1878) Amendment Act 1882 provides the form that a bill of sale must take. ${ }^{18}$ The exact wording must be adhered to or the bill is void, meaning that the lender has no

${ }^{15}$ The benefits to consumers were explained by the Committee on Consumer Credit, chaired by Lord Crowther:

'...[I]t makes a useful contribution to the living standards and the economic and social well-being of the majority of the British people. Individual consumers derive a variety of advantages from its use .... . Loans ... to buy durable goods ... make it possible for consumers to substitute cheaper inside services for more expensive outside services. ... [T] hey enable them to accumulate a stock of consumer capital which might otherwise be impossible and to enjoy a more satisfactory 'mix' of goods and services over time. Shorter-term forms of credit ... confer real benefits, particularly on low income consumers, by making it easier for them to make room in their budgets for the purchase of household necessities ...'

Report of the Committee on Consumer Credit (1971) Cmnd 4596 (the 'Crowther report'), para 3.7.1.

${ }^{16}$ BSA(1878)AA 1882, s.8.

${ }^{17}$ BSA(1878)AA 1882, s.9.

${ }^{18}$ The Schedule to BSA(1878)AA 1882 states:

'This Indenture made the day of, between A.B. of the one part, and C.D. of the other part, witnesseth that in consideration of the sum of $£$ now paid to $A . B$. by C.D., the receipt of which the said $A$. B. hereby acknowledges [or whatever else the consideration may be], he the said $A . B$. 
rights to the goods or to sue the borrower for repayment of the loan, a sanction that is arguably disproportionate. By modern standards, the terminology used is vastly out-dated and many of the requirements serve no useful purpose today.

All goods secured by a bill of sale must be specifically described in a schedule appended to it when the bill of sale is registered. A bill of sale is void (other than against the lender) in respect of any goods described in the schedule not owned by the borrower at the time the bill of sale was executed. ${ }^{19}$ Effectively therefore the lender's security in the bill of sale is enforceable only against the borrower, but not third parties, and is as a consequence of little use to the lender. This essentially prevents bills of sale being of any use against 'future goods'. This of course contrasts with the ability of a company or LLP to give a floating charge over all its present and future goods. There are two other reasons why future goods may not fall within a bill of sale. Firstly, for a bill of sale there must be a transfer of ownership as required by the standard form for a security bill and this is not possible in the case of future goods. Secondly, it may not be possible to specifically describe future goods in the schedule as required. The Law Commission considered proposals to allow for floating charges to be utilised by unincorporated businesses but rejected these proposals on three grounds. Firstly, the Law Commission considered that such charges were an extremely powerful form of security in that such charges as they arise in companies and LLPs are capable of affecting the interests of a very wide group of lenders such as landlords, utility companies and trade suppliers. Often the effect of fixed and floating charges on a company becoming insolvent is to leave very little left to satisfy unsecured lenders who may therefore only recover small proportion of their debts. Secondly, the Law Commission considered such a development would have major implications beyond the law of bills of sale and would undoubtedly require a review of the impact of such a development on insolvency law. Thirdly, the Law Commission considered that, given the potency of a floating charge, an electronic register of floating charges granted by unincorporated businesses would be necessary which could be easily and cheaply searched by all those potentially affected. The Law Commission considered that this would take many years to set up and deflect from the need to reform

doth hereby assign unto C.D., his executors, administrators, and assigns, all and singular the several chattels and things specifically described in the schedule hereto annexed by way of security for the payment of the sum of $f$, and interest thereon at the rate of per cent. per annum [or whatever else may be the rate]. And the said A.B. doth further agree and declare that he will duly pay to the said C.D. the principal sum aforesaid, together with the interest then due, by equal payments of $f$ on the day of [or whatever else may be the stipulated times or time of payment]. And the said A.B. doth also agree with the said C.D. that he will [here insert terms as to insurance, payment of rent, or otherwise, which the parties may agree to for the maintenance or defeasance of the security]

Provided always, that the chattels hereby assigned shall not be liable to seizure or to be taken possession of by the said C.D. for any cause other than those specified in section seven of the Bills of Sale Act (1878) Amendment Act, 1882.

In witness, \&c.

Signed and sealed by the said A.B. in the presence of me E.F. [add witness' name, address, and description.]. '

${ }^{19} \mathrm{BSA}(1878) \mathrm{AA} 1882$, ss 4 and 5. 
the law relating to logbook loans and other forms of bills of sale and necessitate a project in its own right ${ }^{20}$.

The loan amount and repayment date must be specified. This prevents unincorporated businesses from using goods as security for more flexible loans such as a revolving credit facility or an overdraft. It also means that a director is unable to use personal assets to secure a business loan, because the business may never default the repayment date cannot be specified in advance.

The registration procedure is cumbersome requiring a number of different steps, including:

(i) attestation of the bill of sale by a solicitor with a statement that before the execution of the bill the effect has been explained to the borrower by the attesting solicitor;

(ii) an affidavit of the time of the making or giving of the bill of sale confirming its due execution and attestation; and

(iii) filing of the bill of sale together with the relevant affidavit at the Queen's Bench Division of the High Court within seven clear days after the making or giving of the bill. ${ }^{21}$

The registration of a bill of sale must be renewed every five years, requiring the procedure to be repeated. ${ }^{22}$

According to the Law Commission, each bill costs somewhere between $£ 35-51$ to register at the High Court. ${ }^{23}$ If the bill is received later than the seven-day period after its execution, there are additional charges for late registration of $£ 50 .{ }^{24}$ The Law Commission estimates that the unnecessary costs of High Court registration to the logbook loans industry are in the region of $f 2$ million annually. ${ }^{25}$

Further, the paper-based system is susceptible to error.

\section{Enforcement by the Lender and Protection for the Borrower and Third-Party Purchasers}

The circumstances in which a lender can enforce a bill of sale by seizing the goods are limited to cases of default by the borrower such as a default making a repayment, bankruptcy, removal of goods from premises, or breach of a condition to maintain the goods e.g. insuring and servicing of a car. ${ }^{26}$ There is an appeal mechanism in that the

\footnotetext{
${ }^{20}$ Law Commission, Bills of Sale: Summary of Responses to Consultation Paper (Law Com No 225, 2016) pp 84 and 85 .

${ }^{21}$ BSA 1878, s. 10.

${ }^{22}$ BSA 1878, s. 11.

${ }^{23}$ Law Commission, Bills of Sale (Law Com No 369, 2016) para 11.6.

${ }^{24}$ Law Commission, Bills of Sale: A Consultation (Law Com No 225, 2015) para 5.27.

${ }^{25}$ Law Commission, Bills of Sale (Law Com No 369, 2016) para 11.1.

${ }^{26}$ BSA(1878)AA 1882, s. 7.
} 
borrower can apply to the High Court, or a High Court judge in chambers, within five days of the seizure. ${ }^{27}$

For third parties, before taking as security or purchasing goods from an individual, it is possible to conduct a search at the High Court to ascertain whether a bill of sale exists. The search is conducted using the borrower's name and postcode at a cost of $£ 45$. A consumer is, however, unlikely to be aware of, or to understand, the process. For new lenders, searches may no longer be carried out due to costs and the difficulty of the process. A new lender might find that there is a previous lender who has registered a bill first. If this is the case then the bill with the earliest stamp on it will take priority. Thus, the second lender will be out of pocket in the event of a default.

\section{B. Problems for Consumers Under the Current Regime}

As previously stated the use of bills of sale has increased exponentially from 3,000 in 2001 to over 30,000 in 2016 . These bills have predominantly been used for so called "logbook loans" secured against a person's car. It is estimated that only 260 of the bills of sale registered in 2014 were granted over goods other than vehicles. ${ }^{28}$ Undoubtedly the whole area of logbook loans gives rise to different concerns as regards the vulnerability of consumers. There are questions relating to exorbitant interest rates and fees; the question of irresponsible lending; and, of course the lack of legal protection for consumers in default, particularly as regards the threat of repossession. Whilst the Financial Conduct Authority requires lenders to treat borrowers in default with forbearance and due consideration the fact remains that some lenders repossess vehicles from borrowers who may be in temporary financial difficulties even in instances where the loan is substantively paid off. To this extent there are complaints that lenders will use a "heavy handed" approach and us the threat of repossession to extract unreasonable and often unaffordable amounts of money, even if the borrower is making an effort to meet the repayments. In this situation it is all too easy to think of the "consumer" as the borrower but diametrically opposed to this is the third-party purchaser who is often an innocent private purchaser and is also a "consumer". The law at present offers no protection to such individuals who equally suffer hardship despite often acting in good faith and without notice of the bill of sale.

However, there appears to be some interesting concerns/possible opposition to change raised by the City of London Law Society (CLLS) Financial Law Committee. ${ }^{29}$ Most notably, it challenges the need for any general system under which individuals may use their goods as security while retaining possession of them. For the few areas of demand, such as purchasing cars, CLLS suggests that other lending approaches such as hire purchase and conditional sale agreements already address those needs, particularly for "low and rapidly

\footnotetext{
${ }^{27}$ BSA(1878)AA 1882, s. 7(5). Under s. 13, the goods must not be removed or sold by the lender until five days have elapsed.

${ }^{28}$ Law Commission, Bills of Sale (Law Com No 369, 2016) para 11.7.

${ }^{29}$ CLLS Financial Law Committee, Response to the Law Commission Consultation on Bills of Sale (2015) available at

http://www.citysolicitors.org.uk/attachments/article/121/Law\%20Commission\%20Bills\%20of\%20Sale\%20Resp onse\%20Form.pdf (Accessed 17 August 2017).
} 
depreciating" value items, such as household goods, and CLLS suggests there is no merit to social welfare in creating a system encouraging loans that far exceed the resale price. They have a valid point, even though they are in the minority. It should also be noted, however, that depreciation is only incurred in those goods that are used. Paintings, wine, spirits can also increase in value. Indeed, some vehicles - i.e. classic cars - are bought as an investment, but those who are in this position are probably the ones that can negotiate the best loan rate and are more likely than not to be able to negotiate at arm's length at the time of consensus ad idem. Furthermore, the proposal by the CLLS tends to focus on bills of sale being used to acquire goods, such as motor vehicles, and glosses over the fact that bills of sale are often used, particularly by unincorporated associations to raise money over goods already in their ownership. Whilst the CLLS suggests that hire purchase and conditional sale agreements could also be used against property already acquired the Law Commission rejected the suggestion at least in part. It agreed that hire purchase and conditional sale agreements should be used to acquire goods and to that extent a bill of sale would no longer be available; however, in relation to goods already owned bills of sale would continue but in the form of a new concept of a goods mortgage under a Goods Mortgages Act $^{30}$.

\section{$\underline{\text { Interest Rates, Charges and Fees }}$}

When the Law Commission conducted its survey, the interest rate charged against goods varied significantly from $60 \%$ to $443 \%$. On their calculation, based on a $£ 1,500$ loan over 12 months, the interest at a $60 \%$ rate was $£ 900$ making a total repayment of $£ 2,400$. With an interest rate at $443 \%$, the interest was $£ 6,646.20$ making the total repayment $£ 8,146.20$. Such rates are clearly punitive especially when comparing them to hire purchase or unsecured high street banking rates of $5 \%$.

From the consumer perspective, it is contended that those having no option but to enter a bill of sale are often the most vulnerable and most unable to afford the high interests rates being charged. It is asserted that this position is amplified when it is considered that lenders often have legal advice giving them a distinct and disproportionate advantage over the borrower, who is placed in a detrimental position in a little-known form of credit with little redress to the courts.

In addition to interest rates, there is also a problem of high charges and fees. Taking a car as an example, there are two key issues that a consumer has to navigate if they fall into default. The first is the repayment of any sums overdue along with associated costs, and the second is the repossession of the car and its associated costs. The Citizens Advice Bureau found evidence that these costs are often substantial. For example, phone calls costing $£ 12$, letters $£ 12$, late payment charges $£ 54$, car storage $£ 2$ per day, and car release $£ 800 .^{31}$ There is, at present, no relief for the borrower; these sums can be accumulated ad infinitum and is demonstrably unfair.

\footnotetext{
${ }^{30}$ Law Commission, Bills of Sale (Law Com No 369, 2016) para 4.39.

${ }^{31}$ Citizen Advice, Citizens Advice Evidence on Bill of Sale Consumer Lending (2015) page 5, available at https://www.citizensadvice.org.uk/Global/Migrated_Documents/corporate/citizens-advice-evidence-on-billof-sale-lending---february-2015.pdf (Accessed 15 August 2017).
} 
Of particular concern is that the Financial Conduct Authority (FCA), which conducted research into this area, discovered that most of the details on repayments and charges were contained within the small print, poorly explained, there was little flexibility and borrowers felt pressurised and rushed into entering into the agreement. ${ }^{32}$

There have however been some positive steps for borrowers, with additional help following the Consumer Rights Act 2015 (CRA 2015). This requires a term to be fair. ${ }^{33}$ For a term to be exempt from the assessment of fairness it must relate to the main subject matter or to the price paid and the term must also be 'transparent and prominent'. ${ }^{34}$ So the term has to be brought to the attention of the borrower in such a way that the average consumer would have been made aware of it. Further, it should be in plain intelligible language. It is therefore clear that the CRA 2015 covers default notifications and associated charges, as these are ancillary terms.

There is some further protection for the consumer borrower in the form of the Consumer Credit Act 1974 (CCA 1974), as amended by the CCA 2006, but this is limited in its extent and does not provide the same protections as those in hire purchase contracts receive. Oversight of the consumer credit area is the responsibility of the FCA; its remit is to authorise the lender, oversee the conduct of lenders, and undertake enforcement provision against non-compliant lenders. Borrowers are required to be provided with pre-contractual information containing clearly worded information that explains in writing the key terms.

It is asserted that the most useful weapon to wield against a lender to aid the borrower is one of discretion to open up an unfair credit contract and impose new terms on the parties. Before the amendments to the CCA 1974 the court could only reopen the contract if it involved 'extortionate credit,' but since the amendments in 2006 this now covers any unfair term in a credit agreement, unfair enforcement of rights by the lender, or anything done (or not done) by or on behalf of the lender. ${ }^{35}$ It is contended that the most helpful part of the CCA is that the burden of proof now rests with the lender to show that the agreement is fair and the court can rewrite key aspects of the agreement so that any debt is reduced, discharged or rebated under it. Thus, it is argued that the judiciary have some powerful tools to assist the borrower and to that extent it would be in the interest of the borrower to default, as most county court judges would probably be more than happy to rip into these agreements. Sadly however, many of the sub-prime borrowers would not be able to afford the court fees and would probably have to be a litigant in person which may result in them shying away from seeking the court's help in preventing the implementation of crippling interest rates.

In many respects, the interest rates on bills of sale credit can be seen as in the same range as payday loans. While bills of sale are for a different type of credit and payday loans are focused at very short-term needs over a month or two, similar patterns of high costs for

\footnotetext{
32 Financial Conduct Authority, Consumer Credit Research: Payday Loans, Logbook Loans and Debt Management Services (2014) page 29.

${ }^{33}$ CRA 2015, Part 2, s. 62(1).

${ }^{34}$ CRA 2015, Part 2, s. 64(2).

${ }^{35}$ CCA 1984 , s. 140 A, B and C.
} 
vulnerable borrowers become apparent. Payday loans are now subject to fairly stringent safeguards following much criticism, including the FCA introduction of a price cap on shortterm high-cost lending in 2015.

The regulation imposed a total cap of $100 \%$ of the amount borrowed so that the borrower could not be charged more than this in interest, charges and fees. ${ }^{36}$ Prior to this, it was a free-for-all unregulated area where significant degrees of unfairness were practiced. It is contended that in reality bills of sale need to be regulated in a similar way, and quite rightly, the Citizens Advice Bureau have also made a call for the FCA rules to be so extended, in spite of the difficulties caused by logbook loans sometimes exceeding the short-term credit definition of 12 months. ${ }^{37}$

\section{Limited Protection for Consumer Borrowers}

With logbook loans, the ownership of the vehicle moves from the borrower to the lender and the result is that no court order is needed before a lender can repossess the vehicle. This, according to Citizens Advice Bureau, encourages irresponsible lending and debt collection practices by reducing the onus on the lender to negotiate when the borrower gets into payment difficulties because they can just seize the asset. ${ }^{38}$ It is worth noting here that, despite the high cost of the credit and the risk of loss of the asset, for logbook loans it is normal for firms to only lend up to half of a car's value. ${ }^{39}$

The matter of irresponsible lending will be explored under the next subheading. In relation to debt collection practices, analysis by Citizens Advice Bureau shows worrying trends in spite of the introduction of a voluntary code of practice in 2011 , to which most logbook lenders are subject. ${ }^{40}$ In a review of more than 23,000 cases of significant debt problems handled by the organisation between April and September 2013, it found 127 cases which involved a logbook loan. ${ }^{41}$ There were 119 cases recorded as lenders not dealing with borrowers in financial difficulties in a fair and proportionate manner, involving lenders being unwilling to negotiate, and threatening repossession when borrowers were unable to

\footnotetext{
${ }^{36}$ See Policy Statement 14/16 Detailed rules for the price cap on high-cost short-term credit.

${ }^{37}$ Citizen Advice, Citizens Advice Evidence on Bill of Sale Consumer Lending (2015) page 9, available at https://www.citizensadvice.org.uk/Global/Migrated Documents/corporate/citizens-advice-evidence-on-billof-sale-lending---february-2015.pdf (Accessed 14 August 2017).

${ }^{38}$ Citizen Advice, Citizens Advice Evidence on Bill of Sale Consumer Lending (2015) pages 4-5, available at https://www.citizensadvice.org.uk/Global/Migrated Documents/corporate/citizens-advice-evidence-on-billof-sale-lending---february-2015.pdf (Accessed 14 August 2017).

${ }^{39}$ https://www.moneyadviceservice.org.uk/en/articles/logbook-loans (Accessed 15 August 2017).

${ }^{40}$ The Consumer Credit Trade Association (CCTA), implemented a code of practice for their members from 1st February 2011. Consumer Credit Trade Association, Code of Practice: Bills of Sale for Consumer Lending Regulated Under the Consumer Credit Act 1974 - Updated February 2016, available at https://www.ccta.co.uk/wp-content/uploads/2016/06/Bills-of-Sale-Code-of-Practice-2017-consumer.pdf (Accessed 15 August 2017).

${ }^{41}$ Citizen Advice, Citizens Advice Evidence on Bill of Sale Consumer Lending (2015) page 5, available at https://www.citizensadvice.org.uk/Global/Migrated Documents/corporate/citizens-advice-evidence-on-billof-sale-lending---february-2015.pdf (Accessed 14 August 2017).
} 
keep up their payments and fell into arrears. ${ }^{42}$ There were 63 cases where consumers reported experiencing aggressive debt collection and repossession practices, causing both financial and psychological harm. ${ }^{43}$ This is clearly not acceptable and it is contended that access to legal advice or support is urgently needed and the lack of this is exposes Borrowers to unfair treatment. There is therefore an urgent need to rebalance the power between lenders and borrowers.

This is not to suggest, nor is it contended, that there is no protection currently available. Under the Consumer Credit Act 1974 (CCA 1974), if the consumer borrower misses two repayments then the lender must send a standard form. ${ }^{44}$ Such defaults can trigger the right of the lender to take enforcement action and seize the goods. The lender must next issue a default notice ${ }^{45}$ and if the default is not made good within 14 days, the lender has the right to seize the property. The default notice also informs the borrower of their right to go to court to ask for additional time to repay the outstanding sums. The court can vary the original terms to provide extra time for the borrower to make payment, or vary the amount of payment, provided that it is just by both parties to do so.

Whilst theoretically sound, it is argued that borrowers are unlikely to be able to afford the court fees if they are also in default and compliance with the Civil Procedural Rules is difficult within the 14-day time limit before the goods are seized and leaves little time to seek legal advice. ${ }^{46}$ A further issue can also be found in the ' research report prepared for Citizens Advice Bureau that demonstrates that consumers are frequently unwilling to engage in a confrontational process ${ }^{47}$ which they see as intimidating. It follows that those who enter bills of sale contracts are the more vulnerable in society, scared of what they do not know or how to engage with the process of making complaints about the agreement or the lender's conduct. Arguably there is a need for greater transparency in the process for vulnerable borrowers.

\footnotetext{
${ }^{42}$ The CCTA code states that lenders should 'allow for alternative, affordable payments amounts when the consumer or his appointed debt advisor... makes a reasonable proposal' (para 4.8.5); seize a secured asset 'only when attempts have failed with the customer, to mutually agree a realistic and sustainable arrangement to clear debts' (para 4.8.6); consider cases of financial difficulty 'sympathetically and positively, treat consumers in default or arrears difficulties with understanding, forbearance and due consideration and encourage their customers to contact them should they experience financial difficulty' (para 4.7.3); and suspend the active pursuit of the debt for no less than 30 days if a customer is in default or payment difficulties and being assisted by a debt adviser (para 4.7.5).

${ }^{43}$ The CCTA code requires lenders to meet 'high ethical standards' in debt enforcement (para 4.8.2).

${ }^{44}$ CCA 1974, s. $86 \mathrm{~B}$ and the Consumer Credit (Information, Requirements and Duration of Licences and Charges) Regulations 2007, R19-24.

${ }^{45}$ Consumer Credit (Enforcement, Default and Termination Notice) Regulations 1983, Sch 2, para 9.

${ }^{46}$ Practice Direction 7B r.7.3. requires a precise list, which is 11 sections long, to be provided by the borrower including: statements of basic information such as the date of agreement; the parties' names; notice to be served on the lender or owners giving rise to the claim for the time order; the total unpaid balance and the amount and frequency of payments.

47 djs research, Understanding Consumer Experiences of Complaint Handling (2016) available at https://www.citizensadvice.org.uk/Global/CitizensAdvice/Consumer\%20publications/Understanding\%20consu mer\%20experiences\%20of\%20complaint\%20handling DJS\%20report\%20final June2016\%20(2)\%20(1).pdf (Accessed 15 August 2017).
} 
The rights of the consumer borrower are only of use if he or she can effectively challenge terms and enforcement. Requiring the lender to secure a court order where the borrower has paid over one third of the credit total, which forms part of the Law Commission's proposed reforms to the regime, would, it is argued, appropriately shift the onus to the lender and thereby enable the courts to provide the necessary protection. Often however the borrower has difficulties where less than one third of the total amount has been paid as, in such a case there is no need for a court order. ${ }^{48}$ Access to the Financial Ombudsman Service (FOS) is vital in providing a less daunting and a free service. This requires the consumer to first complain to the lender and then give them eight weeks to resolve the issue. It is however contended that this procedure is flawed in that during the eight weeks period the goods could already have been seized and significant costs incurred. Goods such as cars may form an indispensable part of a person's personal and working life, and once seized and sold on, effective redress is impractical and arguably unfair.

For hire purchase terms, irrespective of whether the borrower is in financial difficulties, goods can be returned once one-half of the hire purchase loan is repaid. ${ }^{49}$ Similar legal rights would clearly be beneficial for bills of sale and more generous provisions are a welcome inclusion in the Law Commission proposals.

\section{$\underline{\text { Irresponsible Lending }}$}

The high cost of borrowing and inappropriate debt collection practices are both linked with the wider issue of irresponsible lending and consumer over indebtedness. Consumers taking bills of sale these loans may have few other options left. Evidence shows that borrowers are often borrowing from Peter to pay Paul and become overloaded with debt. This is a point reinforced by the aforementioned statistics from Citizens Advice Bureau reviewing more than 23,000 cases of significant debt problems. ${ }^{50}$

The findings from the analysis show that people with logbook loans had on average: a total of ten debts (double the number of loans held by all debt clients); $57 \%$ also had one or more other type of high cost credit; $37 \%$ also had one or more payday loan; and a total amount of debt across all loans of $£ 13,500$. The research also found that $33 \%$ of people who took out a logbook loan were unemployed and $27 \%$ not working due to things like caring responsibilities or ill-health.

As Citizens Advice Bureau Chief Executive Gillian Guy has cautioned:

'Predatory logbook lenders are driving people into debt... Any decent lender knows it is irresponsible to lend to people who already struggling. Yet logbook lenders are showing a complete disregard for their customers by

\footnotetext{
${ }^{48}$ For hire purchase terms, once the hirer has repaid one third of the hire purchase loan, the lender may only repossess the goods with a court order (Consumer Credit Act 1974, s.90).

${ }^{49}$ Consumer Credit Act 1974, s. 99.

${ }^{50}$ Citizen Advice, Citizens Advice Evidence on Bill of Sale Consumer Lending (2015) page 3, available at https://www.citizensadvice.org.uk/Global/Migrated Documents/corporate/citizens-advice-evidence-on-billof-sale-lending---february-2015.pdf (Accessed 14 August 2017).
} 
using outdated language, not checking if loans are affordable and not treating people fairly. People struggling with their finances should be directed towards advice, not more debt... Logbook loans can be a particularly toxic form of credit as some lenders combine the risk and poor checks of a payday loan with threatening behaviour often used by bailiffs... ${ }^{51}$

Concerns relating to irresponsible lending have also been noted by the FOS, which states that consumers who come to them question whether they should have been lent the money. It stresses that the regulators have recognised lenders' responsibility to make sure customers are lent only what they can afford. ${ }^{52}$ How this is accurately assessed needs to be fully explained in a transparent process with accurate valuations, but this also gives rise to exaggeration issues (see Part $D$ below). In the absence of tighter control over irresponsible lending, or caps on the cost of credit in line with payday loans, it is contended that the temptation for lenders to give loans to people in desperate financial difficulties will continue. As already noted, the lender can seize the asset if payments fall behind but also has the advantage that, in securing the loan against an important asset such as car, consumers are forced to prioritise the payment of logbook lenders.

Many problems could of course be entirely avoided if there was rigorous screening of borrowers before credit is advanced. There is a requirement to explain products and to check the borrower's financial ability to make all the repayments in the FCA Consumer Credit sourcebook (CONC). ${ }^{53}$ The Office of Fair Trading Irresponsible Lending Guidance, which requires an assessment of affordability and negative financial implications for the borrower, has been incorporated into $\mathrm{CONC}^{54}$ So too have the requirements of the EU Consumer Credit Directive to ensure that lenders assess the borrower's creditworthiness, using sufficient information. ${ }^{55}$

Referring back to the Mortgage Market Review: Responsible Lending in July $2010^{56}$ the then Financial Services Authority recommended that lenders should verify all income and expenditure before the money for a mortgage is advanced. It is contended that if this robust process was adopted and applied to reformed logbook loans regime the lenders' practice would not expose themselves to unnecessary risk, assuming the borrower has provided accurate information for such an assessment, such as the over-valuing of assets.

51 Available at $\underline{\text { https://www.citizensadvice.org.uk/about-us/how-citizens-advice-works/media/press- }}$
releases/people-with-logbook-loans-are-overloaded-with-debt/ (Accessed 15 August 2017). http://www.fos.org.uk/publications/consultations/2016-01-11-Law-Commission-consultation-responselogbook-loans.pdf (Accessed 16 August 2017).

${ }^{53}$ Available at https://www.handbook.fca.org.uk/handbook/CONC.pdf (Accessed 16 August 2017).

${ }^{54}$ OFT, Irresponsible Lending: OFT Guidance for Lenders (2010) (updated 2011).

${ }^{55}$ Article 8 of Directive 2008/48/EC of the European Parliament and of the Council of 23 April 2008 on credit agreements for consumers and repealing Council Directive 87/102/EEC.

56 Financial Services Authority, Mortgage Market Review: Responsible Lending (2010), available at https://www.fca.org.uk/publication/consultation/fsa-cp10-16.pdf (Accessed 15 August 2017). 
Furthermore, CLLS proposes, if the mortgage system goes ahead, there should at least be some substantial minimum medium-term value in goods permitted to be given in security.

The FCA launch this year of a consultation on changing the rules on assessing creditworthiness in consumer credit is to be welcomed. Amended rules and guidance would clarify what the FCA expects of firms in assessing creditworthiness and make it easier for the FCA to supervise the market. ${ }^{57}$ Notably, there are proposed reforms to the meaning of affordability $^{58}$ and to determination of income and expenditure including limitations on the ability to self-certify. ${ }^{59}$ Thus, it is argued that these provisions clearly need to apply to any new system introduced.

\section{Third-Party Buyers}

An innocent third-party purchaser of a motor vehicle subject to a logbook loan has no protection vis a vis the lender. As previously seen the borrower in taking out a logbook loan transfers the legal title to the lender and retains no interest in the vehicle whatsoever and as such can pass nothing on to the third-party purchaser who remains vulnerable to seizure of the car by the lender. This is a clear application of the nemo dat rule and the law offers no protection to a third party who buys goods subject to a bill of sale, even if the third party has acted in good faith and without notice since it is the lender's title that defeats the title of such a purchaser. This appears unfair when compared to hire purchase contracts where a lender will lose all rights in a vehicle secured on hire purchase terms to an unsuspecting and innocent private bona fide third party private purchaser. ${ }^{60}$ Under the proposed reforms this protection will be extended so that lenders will no longer be able to repossess vehicles from, or indeed reach financial settlements, from innocent private purchasers who purchase in good faith and without notice of a goods mortgage. This protection will not only encompass motor vehicles but all goods. At the same time however, the Law Commission has proposed that the new Act would contain a provision giving a power to repeal the protection granted to private purchasers of vehicles if vehicle provenance checks were to become free (or nearly free) and a routine part of buying a second-hand vehicle. ${ }^{61}$

\section{Problems for Businesses Under the Current Regime}

The significant complexity and cost of the documentation and registration requirements for a bill of sale prove a barrier to such arrangements being entered into, limiting the credit market. The justification for this is no longer evident. It appears that it is quite common

\footnotetext{
${ }^{57}$ FCA, Assessing Creditworthiness in Consumer Credit: Proposed Changes to Our Rules and Guidance (2017), available at https://www.fca.org.uk/publication/consultation/cp17-27.pdf (Accessed 16 August 2017). The consultation closes on 31 October 2017.

${ }^{58}$ Paras 5.17-5.24.

${ }^{59}$ Paras 5.25-5.39.

${ }^{60}$ Hire Purchase Act 1967, s.27.

${ }^{61}$ Law Commission, Bills of Sale (Law Com No 369, 2016) p.136 para 27.
} 
practice for those registering a bill of sale at the High Court to also register a financial interest over motor vehicles with an asset finance registry such as HPI, Experian, Instant Car Check or CDL. These are private registries run by private companies, but they are searchable by private individuals and consumers for a small fee via websites and apps. Additionally, private individuals who are also lenders can also register a logbook loan by joining as a 'trader' for a small fee. ${ }^{62}$ Indeed, these registries are so widely searched by motor traders and lenders in the motor trade industry that the Consumer Credit Trade Association code of practice requires its members to register logbook loans with such an asset finance registry within 24 hours of the documentation being signed ${ }^{63}$. These registries are also searchable by private individuals as well as traders.

This is far more practical as an asset finance registry can be searched electronically whereas the High Court register needs to be physically searched. It is argued that there should be a complete abolition of any registrations at the High Court. This would be very welcome if implemented, and it would also have the benefit of removing costly hoops that the lender has to jump through, such as having the High Court stamp the bill of sale within seven days of its execution. As it stands, these asset databases are predominantly concerned with vehicles. What is arguably needed is greater flexibility and that such electronic registers should adapt to the registration of other assets such as paintings, antiques, bottles of wine etc. This may be problematical in that such property would need to be identifiable, though one solution may be, using floating charges as an analogy, is to allow for registration against a class of assets.

Making the process easier would encourage more of these secured credit arrangements, freeing up assets such as paintings and antiques etc. to be used in credit bargains whilst still allowing the goods to be enjoyed. Such a development would also open a significant new route of credit for unincorporated businesses using their business assets. It is arguable that such enterprises would also be in a stronger position to negotiate at arm's length for better terms.

Reform to the requirement that bills of sale for specified loan amounts and repayment dates could further be argued to open and expand the credit market for businesses. Removing such restrictions would enable businessmen to use their assets, for example office equipment, to access cheaper borrowing than that which is available with an unsecured personal guarantee.

\section{The Recommendations for Change}

The Law Commission proposal, supported by the Government, is to repeal the Bills of Sale Acts. This is clearly to be welcomed. The Bills of Sale Acts use Victorian terminology that is out-dated and indecipherable to consumer borrowers and most non-lawyers. The Law Commission clearly illustrated this by quoting that a single sentence in s.4 of the BSA 1878

\footnotetext{
${ }^{62}$ The fee is dependent upon how many logbook loans are registered. Tangentially, it is the lender's responsibility to keep the register up to date.

${ }^{63}$ CCTA, Code of practice: bill of sale for consumer lending regulated under the Consumer Credit Act 1974 (2015), para 3.14
}

Comment [A1]: Which finance registries are we talking about here? There are searchable public registries for aircraft and ships but anything involving a motor vehicle will be a private registry of the type that used to be known as Hire Purchase Information Ltd (see now Experian), accessible to trade and finance parties. If the author knows of a private registry that is searchable by consumers, details should be provided.

Comment [A2]: 
contained 218 words. There is clear support for this move, with $75 \%$ of those responding to the consultation calling for repeal and replacement with modern terminology. ${ }^{64}$

The recommended reforms would stop the use of archaic terminology using terms such as "bill of sale, "security bill" and "personal chattels". This was supported by $81 \%$ of respondents. ${ }^{65}$ Creating a regime of "goods mortgages" would arguably better describe the transaction involved and distinguish it from hire purchase and conditional sale agreements. There would be special consideration for vehicle transactions, so that this can be referred to as "vehicle mortgages".

While more easily understandable, it is arguable that there are still possible problems that could be the source of confusion in the mind of a consumer borrower. Firstly, is the distinction between vehicles and other goods. Secondly, that the term 'mortgage' is often linked by an average person to purchases of houses and to loans over a long period of time. It can be, and is, contended however that the linking of the words 'goods' and 'vehicle' to it should help dispel such associations. The Law Commission suggests that any potential confusion could be mitigated by the use of appropriate warning statements. ${ }^{66}$ Critically, however, this does not address the general problem that people will often not read or understand the terms. One option put forward by the Secured Transactions Law Reform Project, was the use of the term 'security interest' instead.

The other reforms can helpfully be considered in relation to the two areas for concern identified earlier in this paper:

(i) documents and registration, and

(ii) enforcement by the lender and protection for the borrower and third-party purchasers.

The project is now moving forward - a Goods Mortgages Bill was announced in the Queen's speech in June 2017. The Law Commission has consulted on some draft clauses for the Bill ${ }^{67}$

\footnotetext{
${ }^{64}$ Law Commission, Bills of Sale: Summary of Responses to Consultation Paper (Law Com No 225, 2016) para 3.2 .

${ }^{65}$ Law Commission, Bills of Sale: Summary of Responses to Consultation Paper (Law Com No 225, 2016) para 3.11 .

${ }^{66}$ Law Commission, Bills of Sale: Summary of Responses to Consultation Paper (Law Com No 225, 2016) para 3.22 .

${ }^{67}$ Law Commission, Replacing Bills of Sale: A New Goods Mortgages Bill Consultation on Drafts Clauses (2017) available at https://s3-eu-west-2.amazonaws.com/lawcom-prod-storage11jsxou24uy7q/uploads/2015/09/July-2017-Consultation-on-draft-clauses.pdf (Accessed 17 August 2017).
} 
and published its response to the consultation ${ }^{68}$. The draft Bill was published in in September 2017. ${ }^{69}$

\section{Documents}

The goods mortgage documentation will still require some formality in the form of a written document that is signed by the borrower and witnessed. It is contended, however, that there is no requirement for duplication as existing consumer credit legislation already requires regulated credit agreements to be given prescribed documentation setting out the key details. The Law Commission however did not see it like that and considered that such is the importance of a goods mortgage that it should be evidenced in a separate document from a regulated credit agreement and that it should be treated with some formality. In this regard the Law Commission retained the need for the mortgage document to be signed by the borrower in the presence of a witness. It was considered that this process would convey to the borrower the seriousness of the transaction which potentially has serious implications for third parties as well as the borrower ${ }^{70}$.

There would no longer be a requirement for the goods mortgage document to state a fixed loan amount or instalments, the absence of which would allow allowing for flexible credit arrangements and guarantees by businessmen. The consultees (67\%) were clearly in favour of dispensing with such a requirement $(67 \%) .{ }^{71}$ Concerns were raised however relating to risks regarding running account credit for consumers, for example, being asked to provide vehicles as security for credit card debt or overdraft facilities. ${ }^{72}$ The Law Commission has responded in its consultation by proposing that only sophisticated borrowers (high net worth individuals and businesses borrowing over $f 25,000$ ) would be able to use goods mortgages to secure running account credit. ${ }^{73}$ This was welcomed by most respondents to the consultation, of the 11 who responded eight fully agreed and one partly agreed. ${ }^{74}$ The $^{2}$ proposed clause is retained in the draft Bill. ${ }^{75}$

\footnotetext{
${ }^{68}$ Law Commission, Goods Mortgages Bill: Response to Consultation and Update on Current Draft Bill (2017) available at https://s3-eu-west-2.amazonaws.com/lawcom-prod-storage-

11jsxou24uy7q/uploads/2015/09/September-2017-Response-to-consultation-and-update-on-draft-bill.pdf (Accessed 15 November 2017).

${ }^{69}$ The Draft Goods Mortgages Bill is available at https://s3-eu-west-2.amazonaws.com/lawcom-prod-storage11jsxou24uy7q/uploads/2015/09/September-2017-Draft-Goods-Mortgages-Bill.pdf (Accessed 15 November 2017).

${ }^{70}$ Law Commission, Bills of Sale (Law Com No 369, 2016) paras 5.14-5.22.

${ }^{71}$ Law Commission, Bills of Sale: Summary of Responses to Consultation Paper (Law Com No 225, 2016) para 4.30 .

${ }^{72}$ Law Commission, Bills of Sale: Summary of Responses to Consultation Paper (Law Com No 225, 2016) paras 4.34-4.35.

${ }^{73}$ Law Commission, Replacing Bills of Sale: A New Goods Mortgages Bill Consultation on Drafts Clauses (2017) paras 3.72 - 3.74 .

${ }^{74}$ Law Commission, Goods Mortgages Bill: Response to Consultation and Update on Current Draft Bill (2017) para 1.52.

${ }^{75}$ See in particular clause 6(4) of the draft Bill.
} 
In relation to goods mortgages that are vehicle mortgages, specific wording was provisionally proposed as mandatory in the consultation on draft clauses:

(i) "Your vehicle may be repossessed if you do not keep up repayments on your loan", and

(ii) "If you sell the vehicle before you pay off your loan, you may be guilty of a criminal offence". ${ }^{76}$

In the response to the consultation, logbook lenders felt that the second statement was not sufficiently strong to deter fraud. ${ }^{77}$ The Law Commission proposed a revised statement:

"You may be prosecuted for fraud if you sell the vehicle or take out another loan on it without mentioning this mortgage."78

It is further proposed that these prominent statements will be adapted for use where other goods are used as security. ${ }^{79}$ Clearly, this would assist in helping borrowers understand the implications of the nature of the agreement, but a consumer borrower may not understand the seriousness or criminality of selling the goods to a third party and use the money to settle the debt over a few monthly payments.

A failure to meet the documentation formalities would mean that the lender would lose rights to the secured goods, but could still sue for repayment of the loan. This is a step change from the failure to comply with the requirements in the 1882 Act which is harsh and disproportionate in that the lender not only loses any right to the goods but also loses the right to sue the borrower for the repayment of the loan ${ }^{80}$. 645 of the consultees agreed with this change though the Citizens' Advice Bureau considered that this sanction would not be a sufficient deterrent and the lenders should be limited to recovering only the principal loan amount ${ }^{81}$.

\section{Registration}

Regarding registration, the Law Commission had proposed that there would be no requirement to register vehicle mortgages at the High Court. This was overwhelmingly supported by $91 \%$ of responses. ${ }^{82}$ Instead, there would be a requirement for protection on

\footnotetext{
${ }^{76}$ Law Commission, Replacing Bills of Sale: A New Goods Mortgages Bill Consultation on Drafts Clauses (2017) para 4.9.

${ }^{77}$ Law Commission, Goods Mortgages Bill: Response to Consultation and Update on Current Draft Bill (2017) para 1.7.

${ }^{78}$ Para 1.77.

${ }^{79}$ Law Commission, Replacing Bills of Sale: A New Goods Mortgages Bill Consultation on Drafts Clauses (2017) para 4.11.

${ }^{81}$ Law Commission, Bills of Sale (Law Com No 369, 2016) paras 5.55-5.60.

82 Law Commission, Bills of Sale: Summary of Responses to Consultation Paper (Law Com No 225, 2016) para 5.3.
} 
the databases at one of the asset registries. ${ }^{83}$ This proposal would arguably represent a welcome modernisation for vehicles, but was potentially problematic that the recommendation applied only to vehicles. With other goods still protected at the High Court, there would therefore be two regimes sitting alongside each other.

Ideally, asset registries could be expanded to include other goods, ${ }^{84}$ whereas the High Court registry would need radical change to be fit for purpose. The justification put forward by the Law Commission is that goods other than vehicles do not normally have a unique identifier such as a registration, engine or chassis number, making the creation of asset registers problematic, but some other goods such as mobile phones or televisions do have a unique serial/IMEI number that could be used. Not all goods however carry such unique identifiers, however the Law Commission's recommendation is that a goods mortgage document should at least be able to contain a specific description of the goods.

There was a call from consultees for the establishment of an electronic register of security interests. ${ }^{85}$ It is encouraging that, while not forming part of the project, the Law Commission recognised the potential benefits of such a register however it did not think that such a register is sufficient to put a private purchaser on notice. Firstly, it considered the public awareness of vehicle provenance checking facilities is low. Secondly, consumers are often confused by cheaper checks that often fail to reveal logbook loans. Thirdly, the cost of such a check by a consumer is relatively high. Fourthly, consumers are often unable to distinguish between a bill of sale and a hire purchase agreement. Whilst the Law Commission saw the benefits of such an electronic register, it recognised that until consumers routinely make use of such a facility it would not provide the degree of consumer protection required. It considered that once electronic registers were used more routinely at no cost then the protection afforded to private purchasers could be repealed. The Law Commission considered that there should be a regulation-making power in the legislation to allow for this $^{86}$.

In 2002, the Law Commission carried out a consultation on the issue of registration. ${ }^{87}$ Arguments against included: expense and inconvenience for what are generally small loans over consumer goods that are not often subject to resale; difficulties of accurately identifying items of personal property; clogging up registers with numerous small consumer

\footnotetext{
${ }^{83}$ There are some practical issues raised by allowing more than one register, which are currently being considered relating to priority of multiple mortgages over the same vehicle. Data sharing is not simultaneous between asset finance registers. Possible approaches include: substantial investment in new systems to enable real-time data sharing between registers; requiring lenders to register with all registers (this would increase time and cost for lenders); and providing indemnity insurance. Law Commission, Replacing Bills of Sale: A New Goods Mortgages Bill Consultation on Drafts Clauses (2017) paras 5.34-5.42.

${ }^{84}$ The private asset registers also include other details such as when a car has been written-off.

85 Law Commission, Bills of Sale: Summary of Responses to Consultation Paper (Law Com No 225, 2016) paras 5.48-5.51.

${ }^{86}$ Law Commission, Bills of Sale (Law Com No 369, (2016) para 8.38.

${ }^{87}$ The Law Commission, Registration of Security Interests: Company Charges and Property Other than Land (Law Com No 164, 2002).
} 
loans; it being unrealistic and unreasonable to expect consumers to search technical registers meaning an obligation would serve no purpose. ${ }^{88}$

Even back in 2002 however the Law Commission considered that there were a number of developments that could make change desirable including:

(a) The increasing number of high value goods acquired on credit such as electronics and sports equipment; the growth of the second-hand market heightening the risk of goods being sold before credit is paid-off; and,

(b) The development of IT to support large databases without a risk of cluttering or complex searches; and,

(c) As mentioned earlier the easier identification of some valuable consumer goods through the increased use of unique serial numbers by manufacturers; and,

(d) Security being created over valuable artefacts that may be far from new (such as antiques). ${ }^{89}$

On that last point, the Law Commission provided more explanation. A use of second-hand goods as security would make it even more desirable to have such interests filed. Two reasons were given. Filing would enable discovery by third parties (the original purpose of the Bills of Sale Acts); and it would give the lender protection against subsequent buyers or other parties taking security interests in the same item. While it was accepted that for some items they would be unlikely to be identifiable by serial number, filing should offer the hope of discoverability. ${ }^{90}$

It can be contended that in the modern era where IT has developed yet further, it would be possible for any electronic register to hold photographs of the asset as well as any description and identifying features. This would therefore be clearly beneficial as any lender would see the condition and quality of the goods used to secure the loan as most of these transactions are often entered into at a distance.

The Secured Transactions Law Reform Project (STR) ${ }^{91}$ has put forward suggestions that could assist in the viability of a more comprehensive register for goods beyond vehicles. The first was that consideration should be given to excluding low value goods or loans either

\footnotetext{
${ }^{88}$ The Law Commission, Registration of Security Interests: Company Charges and Property Other than Land (Law Com No 164, 2002) para 10.35.

${ }^{89}$ The Law Commission, Registration of Security Interests: Company Charges and Property Other than Land (Law Com No 164, 2002) paras 10.39-10.45.

90 The Law Commission, Registration of Security Interests: Company Charges and Property Other than Land (Law Com No 164, 2002) para 10.45.

${ }^{91}$ The STR project aims to examine the law relating to secured transactions and to consider the need and shape of future reform. Its members include representatives from legal practitioners, academics and policymakers as well as lenders and other financial institutions.
} 
from registration completely or requiring registration only to bind a trustee in bankruptcy. ${ }^{92}$ The second is a move to a notice system, as opposed to the current regime of document filing. The introduction of notice filing would provide an opportunity for all mortgages of personal property by consumers to be brought within a single registry..$^{93}$

It is not the first time that arguments such as this have been made. In the 2002 Law Commission Consultation, it was noted that personal property security regimes in other jurisdictions such as New Zealand, Australia and in Canada (where it is known as the Personal Property Security Act (PPSA) regime) do not exclude security created by consumers. ${ }^{94}$ The Law Commission consulted on an option for filing of security interests so as to bind various parties. ${ }^{95}$

The advantages set out by the STR are for a move to a notice PPSA system are compelling, including: filing can be totally electronic, cheap and easy; advance filing is possible, allowing potential lenders to protect themselves and removing the registration gap between creation and registration; the priority rule (i.e. the date of registration) is straightforward; and it is easy to include asset identification data, which can then be the subject of a search. ${ }^{96}$

In the long term, the Law Commission appears supportive, stating:

'We fully appreciate the advantages of an electronic register of security interests. However, there is little Government appetite at this time for the implementation of such a register. Even with Government motivation, such a register is unlikely to be achieved as part of the bills of sale project... We therefore propose to retain the High Court register in the short-term. But our view is that the implementation of an electronic register of security interests is highly desirable... In the long-term we are sympathetic to a general register covering all security interests. We make a recommendation that there should be a regulation-making power to allow for this. ${ }^{97}$

In the shorter term, proposed changes to the High Court scheme would represent real improvements including:

(i) allowing lenders to email documents,

(ii) removing the requirement for an affidavit,

${ }^{92}$ STR, Professor Sarah Neild, Discussion Paper Series: Personal Property Security and Consumers (2016) page 8 available at https://stlrp.files.wordpress.com/2017/01/nield-consumers.pdf (Accessed 14 August 2017).

${ }^{93}$ STR, Professor Sarah Neild, Discussion Paper Series: Personal Property Security and Consumers (2016) page 9 available at https://stlrp.files.wordpress.com/2017/01/nield-consumers.pdf (Accessed 14 August 2017).

94 The Law Commission, Registration of Security Interests: Company Charges and Property Other than Land (Law Com No 164, 2002) para 10.48.

95 The Law Commission, Registration of Security Interests: Company Charges and Property Other than Land (Law Com No 164, 2002) para 10.50.

96 STR, Professor Louise Gullifer, Discussion Paper Series: Registration (2017) page 24 available at https://stlrp.files.wordpress.com/2017/01/gullifer-registration.pdf (Accessed 17 August 2017).

${ }^{97}$ Law Commission, Bills of Sale: Summary of Responses to Consultation Paper (Law Com No 225, 2016) paras 6.54-6.55. 
(iii) abolishing the time limit for registration, and

(iv) re-registration would be required only every ten years.

Following the consultation on the draft clauses, the position after discussions between the Ministry of Justice and HM Treasury about the practical implications of the recommendations is significantly different. The Law Commission states:

'Since that consultation, it has become clear that the government's preferred approach is to establish a single, central, register for all goods mortgages, regardless of the asset involved. This new register will be kept at the High Court.

We are supportive of this alternative approach, on the basis that the registration process will be simplified and the costs for registering, searching and discharging goods mortgages will be reduced. Lenders will be required to submit certain basic information, rather than filing the entire goods mortgage agreement. This will also reduce the administrative burdens on lenders. ${ }^{98}$

The implementation of this policy provides a real opportunity for change, and the draft Bill provides for a register of goods mortgages to be kept with operational details such as the procedure through which registration applications are lodged, or the way that searches of the register are conducted, to be set out in detail in regulations. ${ }^{99}$

The Law Commission expects that these regulations will be the subject of further consultation to ensure that the register is an effective replacement for the current outdated system.

\section{Enforcement by the Lender and Protection for the Borrower and Third-Party Purchasers}

\section{Borrowers}

The Law Commission accepted the need to harmonise consumer protection provisions placing vulnerable borrowers on a par with those in a hire purchase or conditional sale agreements. ${ }^{100}$ Grounds for repossession would be limited to:

\footnotetext{
${ }^{98}$ Law Commission, Goods Mortgages Bill: Response to Consultation and Update on Current Draft Bill (2017) paras 1.101-1.102.

${ }^{99}$ See clause 9 of the draft Bill.

100 The proposals distinguish between sophisticated borrowers, able to obtain advice, and vulnerable borrowers requiring greater protection. The new protections relating to demanding court orders for repossession and the right to have goods back in full settlement of liability under the agreement do not apply, provided that the individual expressly agrees to forgo the protections, to: (1) loans exceeding $f 25,000$ taken out wholly or predominantly for business purposes; or (2) loans to "high net worth" individuals (N.b. the position taken in the consultation on draft clauses differs from that in the 2016 consultation in that there is no longer a requirements that the loan to high net worth individuals be more than $f 60,260)$. Law Commission, Replacing Bills of Sale: A New Goods Mortgages Bill Consultation on Drafts Clauses (2017) paras 2.5-2.9.
}

In its response to the consultation on draft Bill, the Money Advice Trust raised concerns that it was too simplistic to assume that no high net worth individuals would be vulnerable. This failed to, 'take into account issues such as coercive control or domestic violence'. Law Commission, Goods Mortgages Bill: Response to Consultation and Update on Current Draft Bill (2017) para 1.8. However, while the Law Commission accepted 
(i) default on payment,

(ii) default on maintenance or insurance of the goods, and

(iii) bankruptcy of the borrower.

If the consumer borrower defaults, the lender could be made to apply to the court for a repossession order if the borrower had paid over one-third of the credit total. This was supported by $58 \%$ of respondents. ${ }^{101}$ In response to concerns from the logbook lenders about the cost and delay of seeking court orders when borrowers fail to engage with the process, this would apply only where the borrower has opted-in. Borrowers would be given two opportunities to require a court order, first in the default notice and second after a period of negotiation after that notice. Return of the opt-in notice is proposed to be set at 14 days, with the ability to extend upon request to a further 28 days while they seek debt advice. While the cost of the court order would normally fall upon the borrower if they lose, they would be protected against the lenders' legal fees and other ancillary costs.

Arguably such protection making repossession a last resort would be beneficial not only to consumer borrowers, but also small businesses who may otherwise lose the use of a vital asset such as a van as highlighted by the Federation of Small Businesses in its response to the consultation. It is suggested that there should also be a need to seek a court order to pursue a consumer borrower if, after the goods are repossessed and sold, there is still an amount outstanding.

There will also be a requirement for a court order in order for a lender or debt collector to enter any premises to take possession of the goods without consent from the occupier of the premises. ${ }^{102}$

Further reform includes a right for the borrower to voluntarily terminate the agreement, to release them from the loan by surrendering the goods in full and final settlement of all outstanding amounts. This would be more generous than the rights available under hire purchase, requiring half of the total hire purchase price to have been paid, with no set proportion of the loan amount. This is because the types of property subject to logbook loans do not depreciate so quickly; for example, vehicles that are three years old will have already depreciated by a half or two thirds. Voluntary termination was supported by $91 \%$ of

that, 'any line is arbitrary and may not cover all possible circumstances' it did not agree to maintain the $£ 60,260$ threshold as removing the threshold, 'provides these borrowers with greater flexibility' (para 1.9).

See clause 6 of the draft Goods Mortgages Bill and the high net worth conditions in clause 7.

${ }^{101}$ Law Commission, Bills of Sale: Summary of Responses to Consultation Paper (Law Com No 225, 2016) para 6.2 .

${ }^{102}$ See clause 16 of the draft Bill. 
respondents, ${ }^{103}$ its immediate availability by $75 \%{ }^{104}$ and it acting as full and final settlement by $70 \%{ }^{105}$.

The draft Bill preserves the requirement, under the BSA 1882, to wait five working days between taking possession and sale of the secured goods. However, following the consultation on draft clauses the Law Commission has modified its position.

The main case against the five-day period was put by Boodle Hatfield, in relation to high net worth individuals and business borrowers. They highlighted the additional costs associated with storing, maintaining and insuring for five days. The Law Commission was convinced that businesses borrowing over $£ 25,000$ and high net worth individuals should be allowed to opt out of this protection in the mortgage agreement, if they wish to do so. ${ }^{106}$

\section{Third-Party Purchasers}

The consultees supported (67\%) reforms that a private individual purchaser should receive good title to goods where he has acted in good faith, without notice. ${ }^{107}$ The Law Commission considered that this protection should apply to all forms of goods where the purchaser pays money or makes some other form of payment, such as exchange. Indeed, it considered that purchasers of other goods were probably in need of greater protection due to the absence of an asset register for these goods. ${ }^{108}$

In the response to the consultation on draft clauses, some lender raised concerns that protected purchased without "actual notice" would lead to the potential for fraud, and in particular that purchasers would deliberately not search the goods mortgage register. ${ }^{109}$ The Law Commission reiterated that "actual notice" includes "wilful blindness". ${ }^{110}$ This means that private purchasers will be expected to make "such inquiries as an honest and reasonable man would make". The purchaser cannot, therefore, turn a blind eye to the goods mortgages register if they are made aware of it. However, the Commission notes: 'We

\footnotetext{
${ }^{103}$ Law Commission, Bills of Sale: Summary of Responses to Consultation Paper (Law Com No 225, 2016) para 6.39 .

${ }^{104}$ Law Commission, Bills of Sale: Summary of Responses to Consultation Paper (Law Com No 225, 2016) para 6.50 .

105 Law Commission, Bills of Sale: Summary of Responses to Consultation Paper (Law Com No 225, 2016) para 6.53.

${ }^{106}$ Law Commission, Goods Mortgages Bill: Response to Consultation and Update on Current Draft Bill (2017) para 1.147. See clause 18 of the draft Bill.

${ }^{107}$ Law Commission, Bills of Sale: Summary of Responses to Consultation Paper (Law Com No 225, 2016) para 7.2.

108 Law Commission, Bills of Sale (Law Com No 369, (2016) para 8.23 and 8.25.

${ }^{109}$ Law Commission, Goods Mortgages Bill: Response to Consultation and Update on Current Draft Bill (2017) para 1.83.

${ }^{110}$ See Forsythe International (UK) Ltd v Silver Shipping Co Ltd [1994] 1 WLR 1334 and Worcester Works Finance Ltd. v Cooden Engineering Co. Ltd [1972] 1 Q.B. 210.
} 
do not think that this means that the purchaser would be deemed to have notice of entries on a register that the purchaser either did not know about or could not afford to check. ${ }^{111}$

At present, the protection under the Hire Purchase Act 1964 s.29(1) applies only to a "disposition" i.e. a sale, a contract of sale or a hiring under a hire purchase agreement. The Law Commission considered whether that definition of a disposition should also include an exchange or barter so as to bring that Act into line with a new Goods Mortgages Bill. Two consultees, HPI and the Citizens Advice Bureau, did not see a compelling case for extending the protection as it had not come across any difficulties outside of a sale. In any event the notion of a sale was important to furnish the principle of adequate value which went hand in hand with good faith ${ }^{112}$. In response the Law Commission considered that as a sale is regarded as the most common type of transaction the definition adopted by the Sale of Goods Act 1979 s.2(1) should be adopted that is a "sale" is "a contract whereby the seller transfers or agrees to transfer the property in the goods to the buyer for a money consideration, called the price". Such an adoption would mean that transfers where the purchaser provided value would be covered but not gifts and it would not be necessary to distinguish between a "trader" and a "consumer"113.

The Law Commission recommended that a legal duty should be imposed on borrowers to disclose a goods mortgage when selling the goods. There are of course criminal repercussions of a borrower selling goods subject to a logbook loan. It is the case however that not all borrowers are aware of such implications. The Law Commission recognised this and therefore stated that a goods mortgage document should include a prominent statement that the borrower may be committing a criminal offence by selling the goods. The new legislation would give the FCA a regulation-making power to prescribe the wording of this prominent statement, such as: "If you sell the vehicle before you pay off your loan, you may be guilty of a criminal offence" ${ }^{114}$

Following the consultation on the draft clauses, the Law Commission has included in the draft Bill right for lenders to take possession from third party owners (other than in respect of innocent private purchasers). ${ }^{115}$ The Bill allows the court discretion to consider all the circumstances, such as the new owner's willingness to repay the debt, before granting an order for possession. ${ }^{116}$

\section{Guarantor Loans}

\footnotetext{
${ }^{111}$ Law Commission, Goods Mortgages Bill: Response to Consultation and Update on Current Draft Bill (2017) para 1.84 .

112 Law Commission, Bills of Sale (Law Com No 369, (2016) para 8.32.

113 Law Commission, Bills of Sale (Law Com No 369, (2016) para 8.29.

${ }^{114}$ Law Commission, Bills of Sale (Law Com No 369, (2016) para 8.54.

${ }^{115}$ Exercising the right to self-help is risky, given the lender may not know all the circumstances and could face damages for conversion, trespass etc.

${ }^{116}$ See in particular clauses 15 and 25 of the draft Bill.
} 
Citizens Advice have identified a trend for problems with guarantor loans and the need for the Law Commission to guard against guarantors being asked to risk valuable goods, such as vehicles. ${ }^{117}$ The Law Commission has responded to this in its draft clauses, proposing that a goods mortgage could not be used to secure a guarantee, unless granted by a high net worth individual (i.e. probably a sophisticated rather than vulnerable individual). ${ }^{118}$ The results of the consultation on the drafts clauses shows support for the limitation to high net worth individuals, with seven out of the ten responders agreeing and one partly agreeing. ${ }^{119}$ The debt charity, StepChange, argued that ordinary consumers should not be able to use goods as security for guarantees:

'We have evidence from our clients that indicates borrowers can feel significant pressure to prioritise repaying a guarantor loan in order to ensure their guarantor, who could be a close friend or family member, is not asked to repay. This pressure could be seriously aggravated if the guarantor also risked losing valuable goods such as a car.' 120

It was noted that advice agencies suggested that guarantors do not always fully understand their obligations. Combined with the complexity of a goods mortgage, the complexity of a guarantor loan adds to the difficulties borrowers can face in understanding the credit agreement they have taken out and its risks. ${ }^{121}$

The draft Bill confirms that only high net worth individuals can act as guarantors. ${ }^{122}$

\section{Possible Issues with Valuation}

In light of the proposed right to surrender goods in full settlement, the issue of goods valuation may well become more prominent. In the formation of agreed valued, there may be a temptation for the borrower to exaggerate values as a means of securing greater credit or the lender to support the responsible extension of credit. Undervaluation may also occur; this is significant because the true value of the goods is not reflected in the loan. Potentially a lender may deliberately undervalue the goods and this can be seen as similar to pawnbrokers, where at least anecdotal evidence reflects that a ring worth $£ 3000$ may give rise to an offer of only $£ 180 .^{123}$

\footnotetext{
${ }^{117}$ See https://www.citizensadvice.org.uk/about-us/how-citizens-advice-works/media/press-releases/citizensadvice-reports-rise-in-guarantor-loan-problems/ (Accessed 17 August 2017).

${ }^{118}$ Law Commission, Replacing Bills of Sale: A New Goods Mortgages Bill Consultation on Drafts Clauses (2017) paras 3.70-3.73.

${ }^{119}$ Law Commission, Goods Mortgages Bill: Response to Consultation and Update on Current Draft Bill (2017) para 1.44 .

${ }^{120}$ Law Commission, Goods Mortgages Bill: Response to Consultation and Update on Current Draft Bill (2017) para 1.44.

${ }^{121}$ Law Commission, Goods Mortgages Bill: Response to Consultation and Update on Current Draft Bill (2017) para 1.45 .

${ }^{122}$ See in particular clause 6(3) of the draft Bill.

${ }^{123}$ https://www.theguardian.com/society/2006/oct/20/socialexclusion.lifeandhealth (Accessed 23 July 2017)
} 
Both sides can exaggerate and there are other areas of law where deliberate exaggeration is permitted contractually, notably in relation to insurance. Strategic positioning by the insured should not be considered in the same way as fraudulently exaggerated statements of value. This to some extent has been supported by the judiciary. For example, in London Assurance $v$ Clare ${ }^{124}$ the jury was directed by Goddard J that an exaggerated statement was not fraudulent

"... for a Man might honestly have exaggerated the idea of the value of the stock, or suggeste[d] a high[er] figure as a starting price." ${ }^{\prime 125}$

It was further echoed by MacKinnon J (as he then was) in Ewer $v$ National Employers' Mutual General Insurance Association ${ }^{126}$ who stated that the claimant who puts down a new replacement cost in lieu of their used value was not acting fraudulently, even though looking at the figure it was described as "preposterous."127 MacKinnon J was clear that it was only a starting figure as the claimant knew that it would be drastically reduced by the insurers. This was followed by Thomas $\mathrm{J}$ in Nsubuga $v$ Commercial Union ${ }^{128}$ and finally the Court of Appeal commented on exaggeration in Orakpo $v$ Barclays Insurance Services Co $L t d^{129}$ where Staughton LJ stated:

"It is, I think, clear that the part of the claim based on loss of rent was indeed grossly exaggerated [...] Of course, some people put forward inflated claims for the purpose of negotiation, knowing that they will be cut down by an adjuster [...] From time to time claims are patently exaggerated [...] In such a case [...] the falsity of what is stated is readily apparent. ${ }^{1130}$

And Hoffmann L.J. suggested that there should be some objective element and held on the point of exaggeration:

"[...] One should naturally not readily infer fraud from the fact that the insured has made a doubtful or even exaggerated claim. In cases where nothing is misrepresented or concealed, ... this value may well represent the difference due to depreciation, wear and tear, the insurer is doing no more

\footnotetext{
${ }^{124}$ (1937) 57 LIL 254

${ }^{125}$ Above p. 268

${ }^{126}$ [1937] 2 All ER 193

${ }^{127}$ Above p.203

128 " [...] it is my view that very clear evidence of fraud would be required because one has to accept as a matter of commercial reality that people will often put forward a claim that is more than they believe that they will recover. That is because they expect to engage in some form of "horse trading" or other negotiation. It would not generally in those circumstances be right to conclude readily that someone had behaved fraudulently merely because he put forward an amount greater than that which he reasonably believed he would recover..." [1998] 2 Lloyds Rep 682 p.686

${ }^{129}$ [1995] LRLR 433

${ }^{130}$ Above p. 450
} 
than indemnifying the insured at the lowest possible sum, which would probably reflect the trade value of the car and not the retail price."131

The insured is positioning himself for the purposes of negotiation and, as the courts have observed, this exaggeration is lawful based on objective information available such as vehicle book values published in trade journals like Glass's Guide or motoring magazines.

But credit transactions are a different type of contract because in insurance cases there is a duty of good faith to be honest when making a claim. In credit transactions negotiations start pre-contractually. Strategic positioning is important and has its limits as a consumer will always be subject to the offers from the lender/buyer as they are the experts in their area when determining the value as they have to protect their liability. As has been seen above regarding pawnbroking whatever the lender wants to offer need not reflect a reasonable value for the goods and this can open up the area to significant abuse.

\section{E. Conclusions}

The reforms that are indicated by the Law Commission are very welcome. Having a separate regime for consumers and non-consumers should benefit the industry. But a sole trader is equally as vulnerable as an individual consumer. Ensuring that court orders for repossession are a mandatory requirement will place the consumer borrower in a better position as the whole agreement could then be scrutinised by the court to ensure that it is fair. The lender would bear the initial cost meaning that the impecunious borrower will not have to pay the initial court fees. Further the Law Commission proposes that it will be mandatory for lenders to give borrowers notice of their right to a court order on both the default notice and by means of a separate opt-in notice issued immediately before taking enforcement action. The basis behind the opt-in notice is basically to save costs. Thus, once the default notice has been served informing the borrower that they have the right to request that the lender seek a court order, only if the borrower responds to this notice would the lender be required to go through the court process ${ }^{132}$. The Law Commission considered that such an opt-in notice will go a long way towards encouraging forbearance and co-operation between lenders and borrowers and that it should help reduce repossession which should be a last resort.

It is however suggested that the role played by the Financial Ombudsman Service may have to be clarified. If a lender wrongfully repossesses without a court order the borrower will have recourse to the FOS. The proposed Bill then provides that the sanctions against the lender are that the goods should be returned to the borrower and further the borrower will have no further liability for any outstanding amounts owing on the loan. In this way there is symmetry between mortgages of goods and the hire purchase regime. For instance, in the FCA Handbook, "Dispute Resolution: Complaints" ${ }^{133}$ if the FOS finds against the lender, it has the power to award compensation to the borrower up to a maximum of $f 150.000$,

\footnotetext{
${ }^{131}$ [1995] LRLR 433 p.451

132 Law Commission, Bills of Sale (Law Com No 369, (2016) para 7.51.

${ }^{133}$ Para 3.7
} 
including compensation for distress and inconvenience ${ }^{134}$. Furthermore, the proposed legislation provides that the FCA consider amending its rules so as to give the FOS jurisdiction over disputes between lenders and private purchasers ${ }^{135}$.

One issue that has perhaps been omitted is that under 1882 Act s. 12 there is a minimum amount to be loaned of $£ 30$ and if the contract was under this amount it would not be enforceable. Today this is insignificant, but in Victorian England, if Dickens's Dictionary of London in $1879^{136}$ is to be believed, this would be close to a year's wages for a footman of that time. This was clearly a significant amount, and distinguished these types of contracts from other credit arrangements of their day. Had this been index linked it would cover contracts over $£ 3000$, but because the original figure still stands this has clearly created this marketplace and significant problems for the poor borrowers.

A welcome safeguard is the proposed prohibition on consumer borrowers in that they would not be permitted to create security over their future property or over all their existing assets, which is a positive step in providing protections against consumer over indebtedness. The FCA consultation on changing the rules on assessing creditworthiness in consumer credit represents another positive development. A move to introduce a maximum cap on the cost of credit could be another option to explore.

\footnotetext{
${ }^{134}$ Law Commission, Bills of Sale (Law Com No 369, (2016) para 7.64.

${ }^{135}$ Law Commission, Bills of Sale (Law Com No 369, (2016) para 8.64.

${ }^{136}$ Charles Dickens, Dickens's Dictionary of London, 1879: An Unconventional Handbook (1879).
} 